\title{
Rapid determination of lactulose in milk by microdialysis and biosensors
}

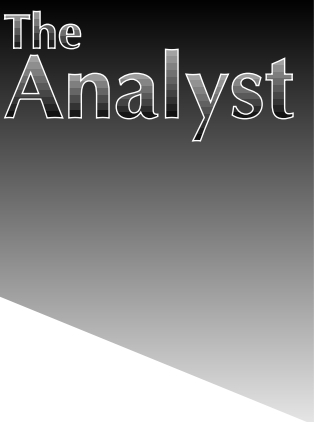

\author{
a Dipartimento di Scienze e Tecnologie Chimiche, Università 'Tor Vergata', Via della Ricerca \\ Scientifica, 00133 Rome, Italy \\ ${ }^{b}$ DISTAAM, Dipartimento di Scienze e Tecnologie Agro-alimentari Ambientali e \\ Microbiologiche, Università degli Studi del Molise, Via De Sanctis, 86100 Campobasso, Italy \\ c Faculté des Sciences et Techniques de Mohammadia, B.P. 146, Mohammadia, Morocco
}

Received 3rd November 1998, Accepted 5th January 1999

\begin{abstract}
A simple and rapid flow system for the determination of lactulose in milk samples was developed. It is based on the hydrolysis of lactulose to galactose and fructose by the enzyme $\beta$-galactosidase immobilised in a reactor. The amount of fructose produced was measured with an electrochemical biosensor based on the fructose dehydrogenase enzyme, $\mathrm{K}_{3}\left[\mathrm{Fe}(\mathrm{CN})_{6}\right]$ as mediator and a platinum based electrochemical transducer. Parameters such as the enzyme immobilisation in the reactor and under the electrode surface, the lifetime of the $\beta$-galactosidase reactor and of the dehydrogenase biosensor and the flow parameters were studied and optimised. Fructose was determined in the range $1 \times 10^{-6}-5 \times 10^{-3}$ mol $1^{-1}$ with an RSD of about $2 \%$ and a detection limit of $5 \times 10^{-7} \mathrm{~mol} \mathrm{l}^{-1}$. The use of a microdialysis probe as the sampling system permitted the direct measurement of lactulose in milk samples without pre-treatment in the range $1 \times 10^{-5}-5 \times 10^{-3} \mathrm{~mol} \mathrm{1}^{-1}$. The sensitivity of the procedure allowed pasteurised, UHT and in-container sterilised milk to be distinguished.
\end{abstract}

In the processing of milk, heat treatment is perhaps the most important operation to ensure its hygienic safety and to obtain a prolonged shelf-life. Nevertheless, during this treatment, some chemical changes occur which affect the nutritional and organoleptic properties of milk. To establish the extent of these changes, the detection of substances which were not present before the process could be 'indicators' of the heat treatment.

Lactulose has been proposed as one of these 'indices' since $1980^{1}$ and considerable research has been carried out to investigate the formation of lactulose during heat treatment of milk and to measure its amount in different types of processed milk. Consequently, lactulose and undenaturted $\beta$-lactoglobulin concentrations have been proposed by some researchers, ${ }^{2-8}$ and adopted by the International Dairy Federation (IDF) 9 and by the European Commission (EC), ${ }^{10}$ as analytical indicators to distinguish UHT milk from in-container sterilised milk. For lactulose, an upper threshold value of $60 \mathrm{mg}$ per $100 \mathrm{ml}$ has been suggested in order to avoid excessive heat damage in UHT milk. ${ }^{11}$ This compound, a disaccharide of galactose and fructose, is not naturally present in raw milk, but it is formed during the heat treatment by isomerization of lactose. ${ }^{12-16}$ Moreover, lactulose is known to induce in humans the growth of bifidobacterial gut flora otherwise absent and it is also used in the treatment of chronic constipation. ${ }^{17-18}$

Several methods have been proposed and applied to measure lactulose in milk. The literature mainly reports GC methods performed on derivatives of mono- and disaccharides; ${ }^{19-21}$ the IDF has published a reference HPLC procedure, ${ }^{22}$ and a spectrophotometric enzymatic method has been proposed by Geier and Klostermayer. 2,3,23

All these methods require expensive apparatus and reagents and skilled operators and are time consuming. For example, the spectrophotometric enzymatic method needs six different enzymes, expensive reagents and about $15 \mathrm{~h}$ to perform the analysis. Moreover, all these methods require deproteination of the sample before the analysis.

An enzymatic electrochemical procedure to simplify the lactulose analysis has been reported. ${ }^{24}$ This method uses the enzyme $\beta$-galactosidase in solution to hydrolyse lactulose to galactose and fructose, then the latter is oxidised by a fructose dehydrogenase enzyme reactor using the $\left[\mathrm{Fe}(\mathrm{CN})_{6}\right]^{3-}$ as mediator and a screen printed electrochemical transducer. A temperature of $50{ }^{\circ} \mathrm{C}$ was necessary to obtain a sufficient degree of hydrolysis and the flow system had to be stopped for an exactly fixed time to allow reproducible recoveries of fructose produced by the enzymatic hydrolysis of lactulose.

In this work, we immobilised $\beta$-galactosidase on glass beads in order to obtain an enzyme reactor with a long lifetime, which was coupled with a highly stable fructose biosensor. The flow system was coupled with a microdialysis sampling technique in order to obtain a constant and continuous recovery of lactulose from untreated milk samples and to allow a real continuous flow measurement of the lactulose at room temperature.

\section{Experimental}

\section{Reagents and materials}

The enzymes D-fructose dehydrogenase (FDH) (EC 1.1.9.11, from Gluconobacter sp., $112 \mathrm{U} \mathrm{mg}^{-1}$ solid) and $\beta$-galactosidase ( $\beta$-gal) (EC 3.2.1.23, from Aspergillus orizae, $9 \mathrm{U} \mathrm{mg}^{-1}$ solid), and all other analytical-reagent grade chemicals were obtained from Sigma (St. Louis, MO, USA).

McIlvaine buffer ( $\mathrm{pH}$ 5.5) was prepared mixing $0.1 \mathrm{~mol} \mathrm{1}^{-1}$ citric acid and $0.2 \mathrm{~mol} \mathrm{l}^{-1}$ disodium hydrogenphosphate and adding Triton $\mathrm{X}-100$ to a final concentration of $0.1 \% \mathrm{v} / \mathrm{v}$. Ferricyanide solution $\left(3 \mathrm{mmol}^{-1}\right)$ was freshly prepared every day in the same buffer.

Preactivated Immobilon AV membranes were obtained from Millipore (Bedford, MA, USA) and polycarbonate membranes $(0.2 \mu \mathrm{m}$ pore size) from Nuclepore (Pleasanton, CA, USA). Aminopropyl glass beads (80-120 mesh, pore size $700 \AA$ ) (CPG) were purchased from Sigma. Dialysis tubes, $50000 \mathrm{Da}$ molecular mass cut-off (MMCO), were obtained from Spectrum 
(Los Angeles, CA, USA). Microdialysis hollow fibres (Filtral AN69) were made of polyacrylonitrile metallyl-sulfonate (Hospal Industrie, Meyzieu, France), with about a $30000 \mathrm{Da}$ MMCO. Nylon and Teflon tubes, $0.5 \mathrm{~mm}$ id, were supplied by Firie (Genova, Italy). A three-way stopcock, T-connections and fittings were obtained from Omnifit (Cambridge, UK).

The spectrophotometric enzymatic method was the 'Lactulose in Milk' test kit (No. 139106, with further reagents) available from Boehringer Mannheim (Mannheim, Germany).

\section{Apparatus}

An LC-4B amperometric detector, (BAS, Lafayette, IN, USA) was used to control the applied potential and to measure the current produced by the reoxidation of the reduced form of the mediator. The detector was connected to a three-electrode walljet cell (Model 656, Metrohm, Herisau, Switzerland) and to a chart recorder (Model L6512, Linseis, Selb, Germany). The working electrode was a platinum electrode $(1.6 \mathrm{~mm}$ diameter, Model MF2013 from BAS) polarised at $380 \mathrm{mV}$ versus an Ag/ $\mathrm{AgCl}$ reference electrode and a gold electrode as the auxiliary electrode. A Minipuls 3 peristaltic pump (Gilson, Villiers-le Bel, France) was used.

\section{Procedures}

FDH biosensor. The FDH enzyme immobilisation procedure was performed on different membranes as follows.

(a) A $25 \mathrm{U}$ amount of FDH enzyme dissolved in $10 \mu \mathrm{l}$ of phosphate buffer $(\mathrm{PB})$ solution $\left(0.1 \mathrm{~mol}^{-1}, \mathrm{pH} 7.0\right)$ was mixed with $5 \mu \mathrm{l}$ of bovine serum albumin (BSA) solution $\left(10 \mathrm{mg} \mathrm{ml}^{-1}\right)$ and $5 \mu \mathrm{l}$ of glutaraldehyde solution $(0.25 \% \mathrm{v} / \mathrm{v})$. The resulting mixture was spread on $1 \mathrm{~cm}^{2}$ of polycarbonate membrane and allowed to dry for $4 \mathrm{~h}$, followed by rinsing in $0.1 \mathrm{~mol}^{-1}$ glycine solution for 30 min to block the unreacted functional groups of glutaraldehyde.

(b) A $25 \mathrm{U}$ amount of FDH enzyme dissolved in PB was added to each side of $1 \mathrm{~cm}^{2}$ of Immobilon AV membrane and allowed to dry for about $2 \mathrm{~h}$. The membrane was then washed in PB-0.1 mol $1^{-1} \mathrm{KCl}$ to remove the residual enzyme not covalently bound.

(c) The same amounts [as in (a)] of FDH enzyme, BSA and glutaraldehyde were added to each side of $1 \mathrm{~cm}^{2}$ of Immobilon membrane, allowed to dry for $1 \mathrm{~h}$ and washed following the same procedure as in (a).

Each kind of FDH membrane was placed on the tip of the Pt electrode and covered with a polycarbonate membrane $(0.2 \mu \mathrm{m}$ pore size) to prevent fouling and microbial attack of the enzyme, then tightly secured with a small piece of a Teflon tube of a suitable diameter.

When not in use, the membranes were either stored dry at $4{ }^{\circ} \mathrm{C}$ or kept in McIlvaine buffer or in a solution of DEAEdextran $(1 \%)$-lactitol $(5 \% \mathrm{~m} / \mathrm{v})$.

$\boldsymbol{\beta}$-Galactosidase reactor. A $10 \mathrm{mg}$ amount of the $\beta$ galactosidase enzyme (9 $\mathrm{U} \mathrm{mg}^{-1}$ solid dissolved in $1 \mathrm{ml}$ of $\mathrm{PB}$ ) was dialysed using a $50000 \mathrm{Da}$ MMCO regenerated cellulose tube against 11 of Mcllvaine buffer, which was renewed three or four times during $24 \mathrm{~h}$. A $100 \mathrm{mg}$ amount of CPG was added to $1 \mathrm{ml}$ of $2.5 \% \mathrm{v} / \mathrm{v}$ glutaraldehyde solution in water and left to react for $1 \mathrm{~h}$ with gentle stirring. The glass beads were extensively washed with distilled water to eliminate the unbound glutaraldehyde, then the purified enzyme was added and left to react for at least $3 \mathrm{~h}$ at room temperature. This was followed by $30 \mathrm{~min}$ of washing with $0.1 \mathrm{~mol}^{-1}$ glycine solution, to block the unreacted groups of glutaraldehyde, then, after a final washing with McIlvaine buffer, the beads were packed in a small piece of Tygon tube $(20 \mathrm{~mm} \times 4 \mathrm{~mm} \mathrm{id})$.
When not in use, the reactor was stored at $4{ }^{\circ} \mathrm{C}$ filled with buffer.

Microdialysis probes. The microdialysis probes were assembled by glueing one or more pieces (1-4) of hollow fibre of different lengths $(1-5 \mathrm{~cm})$ between nylon or Tygon tubes of suitable internal diameter using cyanacrylic glue, and allowed to dry for $24 \mathrm{~h}$.

Measurement procedure. The scheme of the flow system is shown in Fig. 1. The peristaltic pump pushes the buffer solution containing $3 \mathrm{mmol}^{-1} \mathrm{~K}_{3} \mathrm{Fe}(\mathrm{CN})_{6}$ through the microdialysis probe immersed in a standard or a sample solution. The threeway stopcock enables the flow to go through path 1 , where the $\beta$-galactosidase reactor converts the lactulose into galactose and fructose and the latter is detected by the fructose biosensor located in the wall-jet cell. If path 2 is selected, the enzyme reactor is by-passed, and the transducer measures the electrochemical interferences present in milk samples (blank measurements).

\section{Results and discussion}

The enzymatic determination of lactulose is based on the assumption that this compound is the only source of fructose in milk, and the latter is produced only by hydrolysis of lactulose, so the measurement of lactulose is directly correlated with the measurement of fructose. The reactions involved are as follows:

$$
\begin{aligned}
& \text { lactulose }+\mathrm{H}_{2} \mathrm{O} \stackrel{\beta \text {-galactosidase }}{\longrightarrow} \text { galactose }+ \text { fructose } \\
& \text { fructose }+2\left[\mathrm{Fe}(\mathrm{CN})_{6}\right]^{3-} \stackrel{\mathrm{FDH}}{\longrightarrow} \text { ketofructose } \\
& +2\left[\mathrm{Fe}(\mathrm{CN})_{6}\right]^{4-}+2 \mathrm{H}^{+} \\
& 2\left[\mathrm{Fe}(\mathrm{CN})_{6}\right]^{4-} \underset{(+380 \mathrm{mV})}{\longrightarrow} 2\left[\mathrm{Fe}(\mathrm{CN})_{6}\right]^{3-}+2 \mathrm{e}^{-}
\end{aligned}
$$

The fructose coming from the hydrolysis of lactulose in the $\beta$ galactosidase reactor is oxidised to ketofructose at the surface of the fructose biosensor, with the concomitant reduction of the ferricyanide mediator. This latter is reoxidised at the $\mathrm{Pt}$ electrode, giving a current proportional to the fructose, and hence to the lactulose present in the medium.

\section{Fructose biosensor}

Several different examples of this sensor have been reported, ${ }^{25-31}$ but in almost all cases the lifetime of the immobilised FDH enzyme was short, ranging from hours up to 1-2 weeks. Only one paper has reported an enzyme lifetime of more than 1 month. ${ }^{29}$ Because FDH is an expensive enzyme, several procedures to optimise its immobilisation were tried. Fig. 2 shows the best results obtained using the preactivated Immobilon membrane with a slight modification of the immobilisation procedure, which consisted in adding BSA and

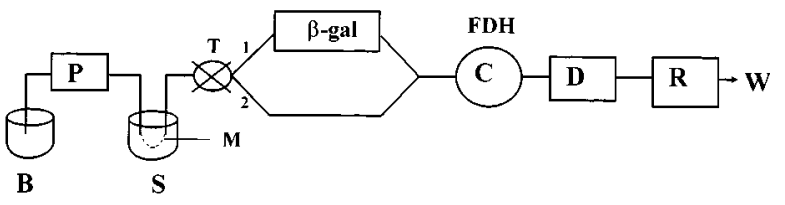

Fig. 1 Scheme of the flow system. $B=$ Buffer + mediator; $P=$ peristaltic pump; $\mathrm{S}=$ sample $; \mathrm{M}=$ microdialysis probe $\mathrm{T}=$ three-way stopcock; $\beta$ gal $=\beta$-galactosidase reactor; $\mathrm{FDH}=$ fructose dehydrogenase biosensor; $\mathrm{C}=$ cell $; \mathrm{D}=$ detector $\mathrm{R}=$ recorder; $\mathrm{W}=$ waste 
glutaraldehyde to the membrane to increase the amount of enzyme bound to the membrane (curve C). Curve A was obtained following the procedure of Xie et al., ${ }^{29}$ but the resulting activity was much lower.

To improve the lifetime of the fructose biosensor, different storage conditions of the membrane were tested. Many papers have reported on enzyme stabilisation by using polyelectrolytes and/or sugars. ${ }^{32-34}$ As can be seen in Fig. 3, substantial differences were found on storing the same membrane at $4{ }^{\circ} \mathrm{C}$ dry or keeping it in the working buffer or in a solution of DEAEdextran (1\%)-lactitol (5\%); in the latter case the membrane still maintained about $50 \%$ of its initial activity after 3 months of use.

This biosensor, when located in the wall-jet cell, measured fructose in the range $1 \times 10^{-6}-5 \times 10^{-3}$ mol $1^{-1}$ with a detection limit of $5 \times 10^{-7} \mathrm{~mol}^{-1}$ calculated as three times the noise of the baseline, and an RSD of $\leqslant 2 \%(n=3)$ and about $4 \%$ in the range $5 \times 10^{-7}-5 \times 10^{-6} \mathrm{~mol} \mathrm{l}^{-1}$. These biosensor features, to our knowledge, are the best so far reported. The optimised conditions for these measurements consisted in the use of McIlvaine buffer $(\mathrm{pH} 5.5),\left[\mathrm{Fe}(\mathrm{CN})_{6}\right]^{3-}$ at a concentration of $3 \mathrm{mmol} \mathrm{l}^{-1}$ and a flow rate of $0.1 \mathrm{ml} \mathrm{min}^{-1}$.

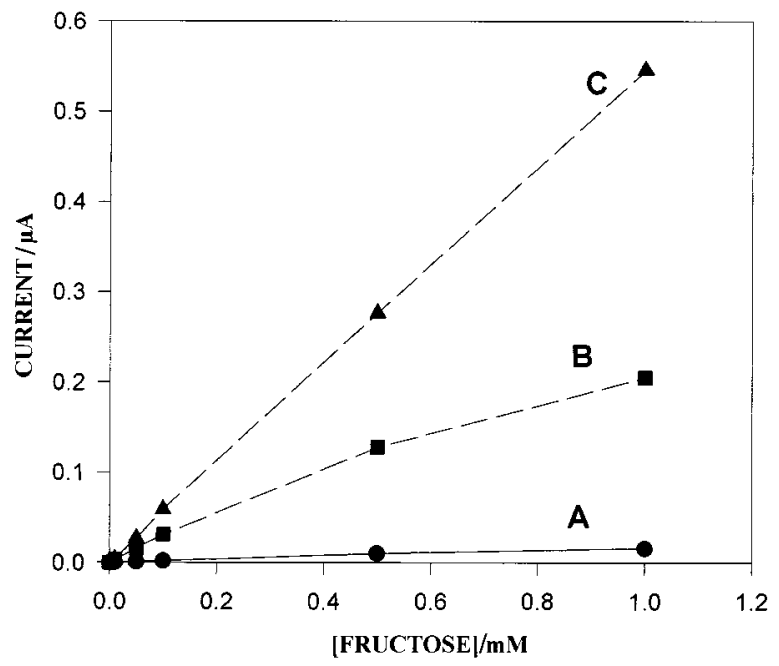

Fig. 2 Amperometric response of FDH enzyme immobilized on different supports: A, polycarbonate membrane + BSA + glutaraldheyde; curve B, preactivated Immobilon membrane; C, Immobilon membrane + BSA + glutaraldheyde.

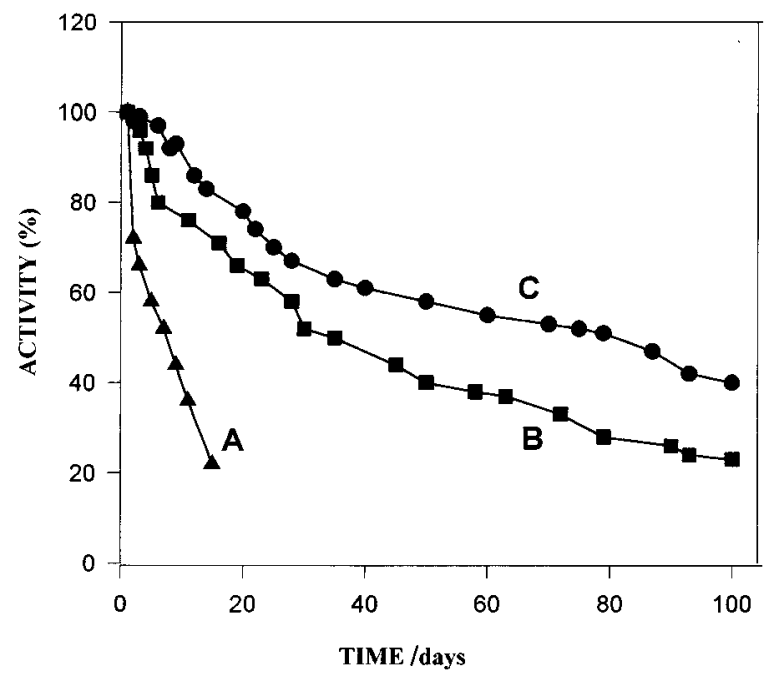

Fig. 3 Lifetime of the $\mathrm{FDH}$ membrane stored at $4{ }^{\circ} \mathrm{C}$ in different conditions: A, dry storage; B, in McIlvaine buffer; $\mathrm{C}$, in 5\% lactitol-1\% DEAE-dextran.

\section{$\beta$-Galactosidase reactor}

The hydrolysis of lactulose to fructose is catalysed by the enzyme $\beta$-galactosidase. In the literature it is reported that the $\beta$ galactosidase from Aspergillus orizae shows the best lactulose to lactose activity ${ }^{35,36}$ compared with $\beta$-galactosidase from other sources, such as Escherichia coli, the reactor was therefore assembled with immobilisation of this enzyme on glass beads. This reactor showed very good performance, converting more than $90 \%$ of lactulose to fructose and maintaining this percentage of conversion for about 3 months when kept at $4{ }^{\circ} \mathrm{C}$ and filled with the working buffer when not in use. Because of the almost total conversion of lactulose into fructose, the calibration curve for lactulose after the introduction of the reactor in the flow system showed a linear range very similar to that obtained for fructose, ranging from $1 \times 10^{-6}$ to $5 \times 10^{-3} \mathrm{~mol} \mathrm{l}^{-1}$ with a detection limit of $10^{-6} \mathrm{~mol} \mathrm{l}^{-1}$ and a similar RSD.

\section{Microdialysis sampling}

Because milk is a very complex matrix, in order to avoid preliminary treatments of the sample a microdialysis sampling technique was used. This very useful technique was first developed for neurochemical analysis in animals ${ }^{37}$ and also applied in our laboratory for monitoring glucose and lactate subcutaneously in humans, ${ }^{38,39}$ but recently it has more often applied in different fields, such as in food analysis. ${ }^{40,41}$

The microdialysis recovery of the analyte of interest is dependent on a number of parameters, such as the length of the fibre and the flow rate. The selection of the flow rate was therefore a compromise between a sufficient recovery by the microdialysis probe, a good conversion by the $\beta$-galactosidase reactor and a reasonable time of analysis. As shown in Fig. 4, on increasing the flow rate from 50 to $400 \mu \mathrm{min}^{-1}$, both the percentage conversion of lactulose into fructose and the recovery by the microdialysis probe decreased. The final choice was a flow rate of $100 \mu \mathrm{l} \mathrm{min}{ }^{-1}$ because it allowed an enzymatic conversion of about $90 \%$, a recovery of lactulose of around $10 \%$ and an analysis time of about 10 min per sample.

Using this flow rate and varying the length and the number of hollow fibres of the microdialysis probe, the recovery of lactulose could be varied; Table 1 shows the relative recoveries with different probes. We used mainly probes with two fibres of $5 \mathrm{~cm}$ length, because the recovery (about 10\%) was sufficient for the determination of lactulose in milk samples.

When this device was integrated in the flow system shown in Fig. 1, we obtained a linear calibration range for lactulose

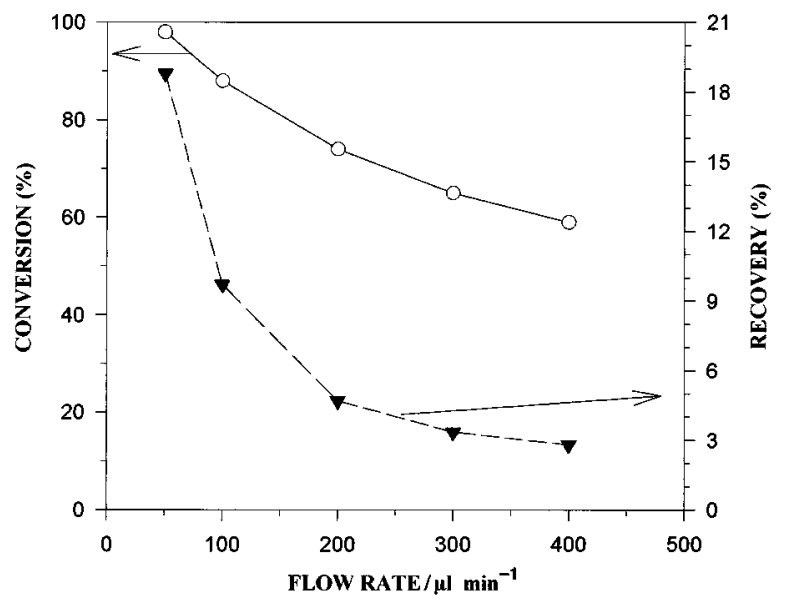

Fig. 4 Effect of flow rate on percentage of enzymatic conversion of lactulose into fructose (circles, left axis), and on the relative recovery through the microdialysis probe (triangles, right axis). 
between $1 \times 10^{-5}$ and $5 \times 10^{-3}$ mol $1^{-1}$ with RSD $\leqslant 2 \%$. In summary, the calibration curves obtained follow the equations $y$ $=352 x+10.6\left(r^{2}=0.9989\right)$ for fructose, $y=324 x+5.4\left(r^{2}\right.$ $=0.9996)$ for lactulose and $y=33.7 x+0.09\left(r^{2}=0.9998\right)$ for lactulose with microdialysis (where $y$ is the current in nA and $x$ is the concentration in $\mathrm{mmol} \mathrm{1}^{-1}$ ).

\section{Analysis of milk: interference studies}

Milk is a very complex matrix containing a non-negligible amount of electroactive compounds, which is a drawback for this kind of amperometric measurement. In fact, because of their low MMCO, permselective membranes such as cellulose acetate or Nafion must be avoided in order to allow the mediator to reach the working electrode. Attempts to solve this problem using a preoxidation cell with a Pt electrode poised at very high potential such as $2 \mathrm{~V}$ versus $\mathrm{Ag} / \mathrm{AgCl}$ reference electrode ${ }^{40}$ or inserting in the flow system another reactor with immobilised ascorbate oxidase gave unsatisfactory results. Their effectiveness was evident only at flow rates as low as $0.02 \mathrm{ml} \mathrm{min}^{-1}$; in this case the electrochemical interferences were reduced to $20-50 \%$ of their initial value, but this low flow rate made the analysis time too long. The problem was circumvented by the use of flow path 2 (Fig. 1): by-passing the $\beta$-gal reactor allows these interferences to be subtracted from the current due to the sample (blank subtraction).

Another interference in milk samples is the lactose present in high concentration (about $4.8 \% \mathrm{~m} / \mathrm{v}$ ) in the sample since it is also a substrate of $\beta$-galactosidase. The hydrolysis of lactose produces galactose and glucose; these sugars are not substrates of the FDH enzyme, but in high concentrations they give a slight response at the fructose biosensor.

We carried out some experiments to evaluate the extent of this interference by measuring with the microdialysis probe the response due to lactose in the range commonly found in milk, i.e., $4.5-5.5 \%$. We found that the response did not vary with the concentration in this range, and was equivalent to a concentration of lactulose of about $0.2 \mathrm{mmol} \mathrm{l}^{-1}$ (about $6 \mathrm{mg}$ per 100 $\mathrm{ml})$.

The current due to an average concentration of $4.8 \%$ of lactose was hence added to the blank current (due to the electrochemical interferences), and the total amount of current was subtracted from the signal obtained by the milk.

\section{Recovery studies}

Recovery tests were carried out by addition of increasing aliquots of lactulose standards to different kinds of milk. The results showed that the calibration curves obtained with milk samples were linear, giving the following equations and correlation coefficients: pasteurised milk, $y=12.9 x+14.9\left(r^{2}\right.$ $=0.9993)$; UHT milk, $y=7.3 x+11.2\left(r^{2}=0.9989\right)$ and incontainer sterilised milk, $y=24.9 x+123\left(r^{2}=0.9978\right)$. However the relative recovery of lactulose when compared with the standard solutions was variable, ranging from 90 to $140 \%$.

Table 1 Lactulose recovery from standard solutions. Flow rate $=100$ $\mu 1 \min ^{-1}$

\begin{tabular}{ll}
\hline Microdialysis probe & Recovery $(\%)$ \\
\hline Single fibre, 4 cm length & 4 \\
Single fibre, 5 cm length & 5 \\
2 parallel fibres, 4 cm length & 8 \\
2 parallel fibres, 5 cm length & 10
\end{tabular}

Because the microdialysis recovery can be affected by several parameters in addition to the length of the membrane and the flow rate, the influence of the $\mathrm{pH}$ and of the ionic strength of the medium was studied. The recovery was not affected by a difference in $\mathrm{pH}$ between 5.5 ( $\mathrm{pH}$ of the buffer), and 6.8 (pH of the milk), but there was a fairly high dependence of the recovery on the ionic strength of the medium.

Table 2 shows how the recovery of lactulose through the microdialysis probe increases as the ionic strength of the medium decreases, being more than double in water than that in McIlvaine buffer. The same behaviour was observed when the buffer was replaced with a solution of $\mathrm{KCl}$; also in undiluted milk, the recovery of the added lactulose was higher. The recovery approached $100 \%$ if the milk was diluted with the working buffer, so this procedure was applied for the analysis of milk in order to minimise the difference in composition both between milk and the working buffer and between different milk samples.

Recovery tests, performed on several different milk samples after a $1+1$ dilution with McIlvaine buffer, showed recoveries ranging from 95 to $105 \%$ for pasteurised, UHT and in-container sterilised milk, as reported in Table 3.

\section{Comparison studies}

Table 4 compares the proposed method and the enzymatic spectrophotometric method. The amount of lactulose in milk was calculated using the standard additions method, performed by adding a fixed amount of lactulose to milk samples in order to eliminate any influence of the matrix on the recovery of lactulose. The results are in good agreement concerning the range of respective standard deviations, while the reproducibility of both methods falls in the range $6-10 \%$ when analysing the same sample on different days.

Table 2 Recovery through the microdialysis probe of lactulose added to different media

\begin{tabular}{|c|c|c|c|c|}
\hline \multirow[b]{2}{*}{$\begin{array}{l}1 \mathrm{mmol} \mathrm{1}^{-1} \\
\text { lactulose }\end{array}$} & \multicolumn{4}{|c|}{ Recovery (\%) } \\
\hline & $\begin{array}{l}\text { McIlvaine } \\
\text { buffer }^{a}\end{array}$ & $\begin{array}{l}1 \mathrm{~mol} \mathrm{l}^{-1} \\
\mathrm{KCl}^{a}\end{array}$ & Milk $^{b}$ & $\begin{array}{l}\text { Distilled } \\
\text { water }\end{array}$ \\
\hline Undiluted & 100 & 109 & 137 & 226 \\
\hline Diluted $1+1$ & 109 & 114 & 98 & \\
\hline Diluted $1+4$ & 149 & 129 & 102 & \\
\hline Diluted $1+9$ & 171 & 146 & 99 & \\
\hline
\end{tabular}

Table 3 Recovery of lactulose added to different milks after $1+1$ dilution with McIlvaine buffer

\begin{tabular}{llll}
\hline & $\begin{array}{l}\text { Lactulose added/ } \\
\text { mg per 100 ml }\end{array}$ & $\begin{array}{l}\text { Lactulose found/ } \\
\text { mg per 100 ml }\end{array}$ & Recovery (\%) \\
\hline $\begin{array}{l}\text { Pasteurised milk } \\
\quad \text { (semi-skimmed) }\end{array}$ & 34.2 & 35.4 & 103 \\
$\begin{array}{l}\text { UHT milk } \\
\quad \text { (semi-skimmed) }\end{array}$ & 34.2 & 34.8 & 102 \\
$\begin{array}{l}\text { UHT milk } \\
\quad(\text { whole) }\end{array}$ & 34.2 & 32.4 & 95 \\
$\begin{array}{c}\text { UHT milk } \\
\quad \text { (semi-skimmed) }\end{array}$ & 34.2 & 35.7 & 104 \\
$\begin{array}{c}\text { Sterilised milk } \\
\quad \text { (whole) }\end{array}$ & 68.4 & 65.7 & 96 \\
$\begin{array}{c}\text { Sterilised milk } \\
\quad(\text { semi-skimmed) }\end{array}$ & 68.4 & 66.0 & 96 \\
$\begin{array}{c}\text { Sterilised milk } \\
\text { (skimmed) }\end{array}$ & 68.4 & 71.7 & 105 \\
\hline
\end{tabular}


Table 4 Lactulose concentration ( $\mathrm{mg}$ per $100 \mathrm{ml}$ ) in different milk samples: comparison of the proposed method and the Boehringer spectrophotometric kit

\begin{tabular}{|c|c|c|c|}
\hline \multirow[b]{2}{*}{ Sample } & \multicolumn{2}{|c|}{$\begin{array}{l}\text { Lactulose concentration/mg per } \\
100 \mathrm{ml}^{a}\end{array}$} & \multirow[b]{2}{*}{$E=\frac{A-B}{B}(\%)$} \\
\hline & $\begin{array}{l}\text { Amperometric } \\
\text { method } \\
(A)\end{array}$ & $\begin{array}{l}\text { Spectrophoto- } \\
\text { metric method } \\
(B)\end{array}$ & \\
\hline $\begin{array}{l}\text { Pasteurised milk } \\
\text { (whole) }\end{array}$ & $4.2 \pm 0.2$ & N.D. & - \\
\hline $\begin{array}{l}\text { Pasteurised milk } \\
\quad \text { (semi-skimmed) }\end{array}$ & $4.9 \pm 0.3$ & N.D. & - \\
\hline $\begin{array}{l}\text { UHT milk } \\
\text { (whole) }\end{array}$ & $34.2 \pm 2.9$ & $36.2 \pm 2.3$ & -5.5 \\
\hline $\begin{array}{l}\text { UHT milk } \\
\text { (semi-skimmed) }\end{array}$ & $30.8 \pm 1.8$ & $26.7 \pm 2.7$ & -15.3 \\
\hline $\begin{array}{r}\text { UHT milk } \\
\text { (whole) }\end{array}$ & $28.5 \pm 0.7$ & $29.7 \pm 2.0$ & -4.0 \\
\hline $\begin{array}{l}\text { UHT milk } \\
\text { (semi-skimmed) }\end{array}$ & $18.8 \pm 1.5$ & $17.8 \pm 1.5$ & 5.6 \\
\hline $\begin{array}{l}\text { Sterilised milk } \\
\quad \text { (whole) }\end{array}$ & $114 \pm 9$ & $115 \pm 4$ & -0.9 \\
\hline $\begin{array}{l}\text { Sterilised milk } \\
\quad \text { (semi-skimmed) }\end{array}$ & $102 \pm 10)$ & $124 \pm 4$ & -17.7 \\
\hline $\begin{array}{l}\text { Sterilised milk } \\
\quad \text { (skimmed) }\end{array}$ & $99 \pm 8$ & $106 \pm 7$ & -6.6 \\
\hline
\end{tabular}

\section{Conclusions}

This new procedure can provide valid support in the determination of lactulose in milk, as it is reliable and accurate; in addition, the analysis time is significantly reduced. Also, online measurements without pre-treatment can be performed.

\section{Acknowledgement}

The authors thank the CNR Target Project on 'Biotechnology' for financial support.

\section{References}

1 I. Martinez-Castro and A. Olano, Milchwissenschaft, 1980, 35, 5.

2 H. Geier and H. Klostermeyer, Milchwissenschaft, 1983, 38, 475.

3 G. R. Andrews, J. Soc. Dairy Technol., 1984, 37, 92.

4 G. R. Andrews and S. V. Morant, J. Dairy Res., 1987, 54, 493.

5 G. R. Andrews, Bull. Int. Dairy Fed., 1989, 238, 45.

6 N. Corzo, T. Delgado, E. Troyano and A. Olano, J. Food Protect., 1994, 57, 737 .
7 L. Pellegrino, P. Resmini and W. Luf, Int. Dairy Fed., 2nd ed. 1995, ch. 20, p 409.

8 L. Pellegrino, I. De Noni and P. Resmini, Int. Dairy J., 1995, 5, 647.

9 B-Doc. 222, International Dairy Federation, Brussels, 1992.

10 Dairy Chemists' Group, Doc. VI/5726/92, EC Commission, Brussels, 1992.

11 B-Doc. 235, International Dairy Federation, Brussels, 1993.

12 G. R. Andrews, J. Dairy Res., 1986, 53, 665.

13 A. Olano and I. Martinez-Castro, Bull. Int. Dairy Fed., 1989, 238, 35 .

14 A. Olano and M. M. Calvo, Food Chem., 1989, 34, 239.

15 J. O'Brien, Int. Dairy Fed., 2nd edn., 1995, ch. 7, 134.

16 M. Villamiel, N. Corzo, I. Martinez-Castro and A. Olano, Food Chem., 1996, 56, 385

17 S. Adachi and S. Patton, J. Dairy Sci., 1961, 44, 1375.

18 T. Mizota, Bull. Int. Dairy Fed., 1996, 313, 43.

19 A. Olano, M. M. Calvo and G. Reglero, Chromatographia, 1986, 21, 538.

20 N. Corzo, A. Olano and I. Martinez-Castro, Rev. Agroquim. Tecnol. Aliment., 1986, 26, 565.

21 R. Lopez-Fandino, N. Corzo, M. Villamiel, T. Delgado, A. Olano, and A. Ramos, J. Food Protect., 1993, 56, 263.

22 International Dairy Federation, FIL-IDF, 1991, 147, 1.

23 R. Andreini, J. Chiodi, I. De Noni and P. Resmini, Sci. Tec. Latt.Casearia, 1990, 41, 472.

24 M. Mayer, M. Genrich, W. Kunnecke and U. Bilitewski, Anal. Chim. Acta, 1996, 324, 37.

25 K. Matsumoto, H. Kamikado, H. Matsubara and Y. Osajima, Anal. Chem., 1988, 60, 147.

26 F. Schubert, D. Kirstein and F. Scheller, Anal. Lett., 1986, 19, 2155.

27 G. F. Khan, H. Shinihara, Y. Ikariyama and M. Aizawa, J. Electroanal. Chem., 1991, 315, 263.

28 T. Ikeda, F. Matsushita and M. Senda, Biosens. Bioelectron., 1991, 6, 299.

29 X. Xie, S. S. Kuan and G. G. Guilbault, Biosens. Bioelectron., 1991, 6, 49.

30 J. Parellada, E. Dominguez and V. M. Fernandez, Anal. Chim. Acta, 1996, 330, 71.

31 R. Antiochia and G. Palleschi, Anal. Lett., 1997, 30, 683.

32 T. D. Gibson, I. J. Higgins and J. R. Woodward, Analyst, 1992, 117, 1293.

33 T. D. Gibson, J. N. Hulbert and S. M. Parker, Biosens. Bioelectron., 1992, 7, 701

34 T. D. Gibson, B. L. J. Pierce, J. N. Hulbert and S. Gillespie, Sens. Actuators B, 1996, 33, 13.

35 M. Harju, Milchwissenschaft, 1986, 41, 281.

36 M. Harju, Milchwissenschaft, 1986, 41, 349.

37 L. Bito, H. Davson, E. M. Levin, M. Murray and N, Snider, J. Neurochem., 1966, 13, 1057 .

38 D. Moscone and M. Mascini, Ann. Biol. Clin., 1992, 50, 323.

39 D. Moscone, M. Mascini, in Uses of Immobilized Biological Compounds, ed. G. G. Guilbault and M. Mascini, NATO ASI Series, Kluwer, Dordrecht, 1993, pp. 115-122.

40 G. Marrazza, A. Cagnini and M. Mascini, Talanta, 1994, 41, 1007.

41 S. Mannino, M. S. Cosio and P. Zimei, Electroanalysis, 1996, 8, 353.

Paper 8/08535H 